\title{
HUBUNGAN SELF ASSESSMENT DENGAN KOMPETENSI KLINIK \\ MAHASISWA KEDOKTERAN
}

\author{
Andra Novitasari ${ }^{1}$, Djuniadi ${ }^{2}$ \\ 1. Universitas Muhammadiyah Semarang, \\ 2. Universitas Negeri Semarang \\ Email : andrascorner@yahoo.com // djuniadi@mail.unnes.ac.id
}

\begin{abstract}
Abstrak
Latar Belakang: Salah satu area kompetensi yang harus dimiliki oleh seorang dokter adalah mawas diri dan pengembangan diri. Self assessment merupakan komponen penting dalam pengembangan diri. Mahasiswa yang sudah mampu melakukan self assessment pada satu komponen kompetensi klinik dengan baik, belum tentu mampu melakukan self assessment dengan mengintegrasikan seluruh komponen kompetensi klinik.
\end{abstract}

Tujuan: Penelitian ini bertujuan untuk menganalisis hubungan antara self assessment dengan kompetensi klinik mahasiswa kedokteran.

Metode Penelitian: Penelitian ini merupakan studi observasional dengan desain cross sectional yang dianalisis dengan uji statistik yang meliputi analisis univariat, dan analisis bivariat terhadap variabel antara adanya self assessment dan kompetensi klinik mahasiswa kedokteran. Sampel dalam penelitian ini sebanyak 60 mahasiswa kedokteran semester ke7. Pengambilan sampel dilakukan dengan teknik consecutive sampling.

Hasil Penelitian: Analisis bivariat menggunakan uji Chi-Square menunjukkan bahwa tidak ada hubungan yang signifikan antara self assessmen dan kompetensi klinik mahasiswa kedokteran ( $\mathrm{p}=0.643$ ).

Kesimpulan: Self assessment terhadap kompetensi klinik belum dapat memberikan gambaran kompetensi klinik yang sebenarnya dimiliki oleh mahasiswa

Kata kunci: self assessment, kompetensi klinik, mahasiswa kedokteran 


\section{Abtract}

Background: One of the areas of competence that must be possessed by a doctor is introspective and selfdevelopment. Self-assessment is an important component in the self-development. Students who are able to do selfassessment on a single component with good medical competence, not necessarily able to do a self assessment by integrating all the components of clinical competence.

Objective: The purpose of this study is to analyze the relation between self-assessment and the medical competence of medical students.

Methods: This study is an observational study with cross sectional design and were analyzed by statistical tests include the univariate analysisand bivariate analysis of the variables between the self assessment and clinical competence of medical students. The sample in this study were 60 medical students of the $7^{\text {th }}$ semesters. Sampling was done by using consecutive sampling.

Result: Bivariate analysis using Chi-Square test showed that there was no significant relation between self -assessment and clinical competence of medical students $(\mathrm{p}=0.643)$.

Conclusion: Self-assessment of medical competence have not been able to give an overview of actual clinical competence possessed by medical students.

Keywords: self-assessment, clinical competence, medical students

\section{PENDAHULUAN}

Pesatnya perkembangan ilmu pengetahuan dan teknologi dengan lintas informasi yang bergerak semakin cepat dan canggih, serta meningkatnya harapan masyarakat dalam pelayanan kesehatan menuntut seorang dokter untuk senantiasa melakukan pengembangan profesionalitas berkelanjutan. Pengembangan profesionalitas berkelanjutan diartikan sebagai kegiatan yang membantu untuk mempertahankan, mengembangkan dan meningkatkan pengetahuan, pemecahan masalah, atau keterampilan teknis sesuai dengan standar kompetensi yang berkaitan dengan profesinya. Dasar pengembangan profesionalitas berkelanjutan adalah adanya mawas diri. Salah satu area kompetensi yang harus dikuasai oleh seorang dokter berdasarkan Peraturan Konsil Kedokteran Indonesia Nomor 11 tahun 2012 tentang Standar Kompetensi Dokter Indonesia adalah mawas diri dan pengembangan diri. ${ }^{1}$

Penilaian diri adalah suatu proses penilaian yang bersifat formatif dimana mahasiswa merefleksi dan mengevaluasi kualitas pekerjaan dan belajarnya, menilai sejauh mana pencapaian kriteria atau standar, mengidentifikasi kekuatan dan kelemahan yang dimiliki untuk perbaikan di masa mendatang. ${ }^{2}$ Proses ini sesuai dengan konsep mawas diri yang harus dimiliki oleh seorang dokter. Mawas diri dan pengembangan diri dalam praktik kedokteran adalah melakukan praktik kedokteran dengan penuh kesadaran atas kemampuan dan keterbatasannya; mengatasi masalah emosional, personal, kesehatan, dan kesejahteraan yang dapat mempengaruhi kemampuan profesinya; belajar sepanjang hayat; merencanakan, menerapkan, dan memantau perkembangan profesi secara sinambung.

Teori pembelajaran modern melihat pentingnya melibatkan mahasiswa dalam melakukan penilaian terhadap apa yang sedang dipelajari. ${ }^{3}$ Teori ini meletakkan dasar peran aktif mahasiswa untuk belajar dan membangun makna dari pengalaman yang diperoleh untuk meningkatkan pemahaman. Beberapa ahli sependapat bahwa keterlibatan mahasiswa dalam proses penilaian diri akan melatih kemandirian serta mempersiapkan mahasiswa untuk menghadapi tantangan ke depan.,5 Mahasiswa yang dilatih ketrampilan menilai diri ketika menghadapi suatu kasus, akan lebih percaya diri terhadap kemampuan dirinya dan akan lebih bertanggung jawab di dunia kerja. ${ }^{6}$ 
Penilaian diri bagi seorang dokter dibutuhkan untuk merefleksi dirinya sebagai dasar pengembangan diri untuk mencapai tujuan kompetensinya klinisnya.

Kompetensi menurut SK Mendikbud No.045/U/2002pasal 21 dan tercantum dalam Standar Pendidikan Profesi Dokter adalah seperangkat tindakan cerdas, penuh tanggung jawab yang dimiliki seseorang sebagai syarat untuk dianggap mampu oleh masyarakat dalam melaksanakan tugas-tugas di bidang pekerjaan tertentu. ${ }^{7}$ Kompetensi klinis adalah kompetensi yang harus dikuasai oleh lulusan dokter sebagai syarat untuk melakukan praktik kedokteran di masyarakat. Pendidikan Kedokteran Indonesia sebagaimana tercantum dalam Peraturan Konsil Kedokteran Indonesia Nomor 11 tahun 2012 tentang Standar Kompetensi Dokter Indonesia mewajibkan sejumlah kompetensi klinis yang harus dikuasai oleh lulusan setelah mengikuti pendidikan dokter. ${ }^{1}$ Kompetensi klinis dan komponennya, bermanfaat untuk dijadikan sebagai standar pelaksanaan program pendidikan kedokteran dan standar minimal pencapaian kompetensi, tidak hanya bagi mahasiswa di akhir pendidikan tetapi juga saat menjadi dokter. Dokter yang memiliki kompetensi klinis adalah dokter yang memiliki pengetahuan, penilaian, ketrampilan, dan pengalaman untuk mendiagnosis dengan benar dan mampu memberikan intervensi pengobatan yang tepat. Kompetensi klinis dapat dilihat melalui pengamatan langsung terhadap kinerja profesional saat praktik. ${ }^{8}$

Kompetensi klinis memiliki beberapa komponen, antara lain : Kemampuan kognitif; Pemecahan masalah diagnostik dan pertimbangan klinis; Ketrampilan interpersonal; dan Profesionalitas. ${ }^{8}$ Pengetahuan klinis dasar dan kemampuan untuk mengaplikasikannya pada situasi nyata merupakan bagian dari kemampuan kognitif. Pemecahan masalah diagnostik dan pertimbangan klinis terdiri dari beberapa komponen, antara lain : (1) menggali informasi dari pasien; (2) melakukan pemeriksaan fisik yang relevan; (3) melakukan atau mengusulkan pemeriksaan penunjang yang relevan; (4) melakukan prosedur klinis dengan tepat; dan (5) menentukan diagnosis banding dan diagnosis kerja. Ketrampilan interpersonal berupa komunikasi efektif dengan pasien dan sejawat. Profesionalitas memiliki arti hubungan yang profesional dan saling menghargai kepada pasien dan penyedia layanan kesehatan lain.

Self assessment bukanlah suatu hal yang mudah untuk dilakukan. Bahkan mahasiswa yang sudah mampu melakukan self assessment pada satu komponen kompetensi klinik dengan baik, belum tentu mampu melakukan self assessment dengan mengintegrasikan seluruh komponen kompetensi klinik yang dibutuhkan untuk menangani suatu penyakit. ${ }^{9}$ Latihan penilaian diri yang dilakukan terus menerus, akan menambah pengalaman mahasiswa untuk semakin menguasai kompetensi tertentu. ${ }^{10}$ Akan tetapi masih belum banyak data dan penelitian yang mendukung penilaian diri dalam pencapaian. ${ }^{11}$ Berdasarkan latar belakang di atas, peneliti tertarik untuk menganalisis hubungan antara self assessment dengan kompetensi klinik mahasiswa kedokteran.

\section{METODE}

Desain penelitian adalah observasional dengan pendekatan cross sectional. Penelitian dilakukan pada bulan Desember 2015 di Fakultas Kedokteran Universitas Muhammadiyah Semarang. Populasi adalah Mahasiswa Fakultas Kedokteran. Pengambilan sampel dilakukan dengan teknik consecutive sampling yaitu semua sampel yang ada dan memenuhi kriteria penelitian dimasukkan dalam penelitian sampai jumlah yang diperlukan terpenuhi. Sampel dalam penelitian ini adalah mahasiswa fakultas kedokteran semester 7 yang bersedia menjadi responden, yaitu sejumlah 60 mahasiswa.

Instrumen penelitian menggunakan kuesioner self assessment yang berisi butir-butir pernyataan yang dapat digunakan responden untuk menilai dirinya sendiri berkenaan dengan kompetensi kliniknya. Skala Pengukuran menggunakan skala likert. Skor 1 adalah Kurang, Skor 2 adalah Cukup, Skor 3 adalah Baik, dan Skor 4 adalah Sangat Baik. Pedoman penilaian : Total skor 30 - <52,5 : Kurang; Total skor 52,5 - <75 : Cukup; Total skor 75 - <97,5 : Baik; Total skor 97,5 120 : Baik Sekali. ${ }^{12}$

Validitas isi kuesioner dilakukan oleh ahli pendidikan kedokteran untuk menilai apakah butir instrumen telah mencakup semua aspek kompetensi klinik yang akan 
dinilai. Uji reliabilitas dilakukan pada 30 mahasiswa kedokteran dan dianalisis menggunakan Cronbach's alpha dengan nilai 0.937. ${ }^{13}$ Instrumen disajikan dalam bentuk Computer-Based Test (CBT) melalui program Modular Object-Oriented Dynamic Learning Environment (MOODLE). Intrumen diisikan oleh responden beberapa saat setelah melaksanakan ujian Objective Structure Clinical Examination (OSCE).

Kompetensi klinik dinilai melalui ujian Objective Structure Clinical Examination (OSCE) yang terdiri dari 6 station dengan sistim yang berbeda, yaitu (1) sistim gastrointestinal, hepatobilier, dan pancreas; (2) sistim ginjal dan saluran kemih; (3) sistim indera; (4) sistim muskuloskeletal; (5) integument; dan (6) sistim reproduksi. Komponen penilaian adalah komponen kompetensi klinik yang harus dimiliki oleh seorang dokter, antara lain (1) anamnesis, (2) pemeriksaan fisik, (3) tes / prosedur klinik dan interpretasi data penunjang diagnostik, (4) menentukan diagnosis dan diagnosis banding, (5) tatalaksana non-farmakoterapi, (6) tatalaksana farmakoterapi, (7) komunikasi dan atau edukasi pasien, serta (8) perilaku professional. Pedoman penilaian : Lulus apabila rerata skor seluruh station > 70 dan Tidak Lulus jika $<70$.
Data diolah menggunakan software SPSS 16.0. Analisis hubungan self assessment dengan kompetensi klinik menggunakan analisis data non-parametrik Chi-Square dengan nilai signifikansi $\mathrm{p}<0.05$.

\section{HASIL}

Responden penelitian terdiri dari 60 mahasiswa. Tabel 1 menunjukkan bahwa responden berjenis kelamin perempuan sebanyak 39 mahasiswa (65\%) dan laki-laki sebanyak 21 mahasiswa (35\%). Mayoritas responden menyatakan bahwa penilaian diri kompetensi kliniknya cukup, yaitu sebanyak 28 mahasiswa (46.7\%). Responden laki-laki sebagian besar menilai dirinya baik, yaitu 12 mahasiswa (57.1\%). Hal ini berbeda dengan responden perempuan yang menilai dirinya cukup dalam hal kompetensi klinik, yaitu sebanyak 21 mahasiswa (53,8\%).

Tabel 2 menunjukkan bahwa mayoritas responden dinyatakan lulus kompetensi kliniknya, sebesar 46 mahasiswa (76.7\%). Hasil ini diperoleh baik dari responden laki-laki, yaitu 12 mahasiswa $(57,1 \%)$, maupun responden perempuan, yaitu 34 mahasiswa $(87,2 \%)$.

Tabel 1. Self assessment berdasarkan karakteristik jenis kelamin

\begin{tabular}{|l|c|c|c|c|c|c|c|c|c|c|}
\hline \multirow{3}{*}{ Variabel } & \multicolumn{10}{|c|}{ SelfAssessment } \\
\cline { 2 - 14 } & \multicolumn{2}{|c|}{ Kurang } & \multicolumn{2}{|c|}{ Cukup } & \multicolumn{2}{|c|}{ Baik } & \multicolumn{2}{c|}{$\begin{array}{c}\text { Sangat } \\
\text { Baik }\end{array}$} & \multicolumn{2}{c|}{ Total } \\
\cline { 2 - 13 } & $\mathrm{n}$ & $\%$ & $\mathrm{n}$ & $\%$ & $\mathrm{n}$ & $\%$ & $\mathrm{n}$ & $\%$ & $\mathrm{n}$ & $\%$ \\
\hline Laki-Laki & 1 & 4.8 & 7 & 33.3 & 12 & 57.1 & 1 & 4.8 & 21 & 100.0 \\
\hline Perempuan & 1 & 2.6 & 21 & 53.8 & 15 & 38.5 & 2 & 5.1 & 39 & 100.0 \\
\hline Total & 2 & 3.3 & 28 & 46.7 & 27 & 45.0 & 3 & 5.0 & 60 & 100.0 \\
\hline
\end{tabular}

Tabel 2. Kompetensi klinik mahasiswa berdasarkan karakteristik jenis kelamin

\begin{tabular}{|l|c|c|c|c|c|c|}
\hline \multirow{3}{*}{ Variabel } & \multicolumn{6}{|c|}{ Self Assessment } \\
\cline { 2 - 7 } & \multicolumn{2}{|c|}{ Lulus } & \multicolumn{2}{|c|}{ Tidak Lulus } & \multicolumn{2}{c|}{ Total } \\
\cline { 2 - 7 } & $\mathrm{n}$ & \multicolumn{1}{c|}{$\%$} & \multicolumn{1}{c|}{$\mathrm{n}$} & \multicolumn{1}{c|}{$\%$} & $\mathrm{n}$ & $\%$ \\
\hline Laki-Laki & 12 & 57.1 & 9 & 42.9 & 21 & 100.0 \\
\hline Perempuan & 34 & 87.2 & 5 & 12.8 & 39 & 100.0 \\
\hline Total & 46 & 76.7 & 14 & 23.3 & 60 & 100.0 \\
\hline
\end{tabular}


Tabel 3 menunjukkan data hasil self assessment tiap butir pernyataan di kuesioner. Mayoritas mahasiswa menilai kompetensi kliniknya kurang pada butir manajemen waktu dan performa saat di bawah tekanan, yaitu sebanyak 19 mahasiswa (31.7\%). Performa secara keseluruhan dinilai cukup oleh 34 mahasiswa (56.7\%). Sebagian besar mahasiswa, atau sebanyak 40 mahasiswa (66.7\%), memberikan penilaian diri baik pada butir anamnesis fundamental four yang relevan. Responden sebanyak 15 mahasiswa (25\%) menilai dirinya sangat baik pada butir informed consent sebelum melakukan pemeriksaan fisik.

Tabel 4 menunjukkan hasil analisis hubungan self assessment dengan kompetensi klinik mahasiswa. Hasil uji statistik didapatkan $\mathrm{p}=0.643(>0,05)$ maka dapat disimpulkan bahwa tidak terdapat hubungan yang signifikan antara self assessment dengan kompetensi klinik.

\section{PEMBAHASAN}

Hasil penelitian menunjukkan bahwa 76.7\% mahasiswa, yang dinilai kompetensi kliniknya melalui ujian OSCE, dinyatakan lulus. Self assessment yang dilakukan oleh responden, mayoritas menilai kompetensi kliniknya cukup. Hasil penilaian diri mahasiswa yang hanya berada pada nilai cukup, sedangkan sebagian besar ternyata dinilai kompetensi kliniknya memenuhi syarat lulus dengan nilai rerata $>70$, dapat disebabkan karena responden yang terlibat dalam penelitian ini merupakan mahasiswa yang masih berada pada tahap akademik (semester 7).

Morris et al dalam penelitiannya di Bavaria tahun 2006 dan Ochsmann et al dalam penelitiannya di Glasgow tahun 2011 menyebutkan bahwa semakin tinggi tahap pendidikan dan banyaknya pengalaman yang sudah dilalui oleh seseorang, mereka cenderung lebih kritis dalam melakukan penilaian diri. ${ }^{14,15}$

Tabel 4. Hubungan self assessment dan kompetensi klinik

\begin{tabular}{|c|c|c|c|c|c|c|}
\hline \multirow{2}{*}{ Kompetensi Klinik } & \multicolumn{4}{|c|}{ Self Assessment } & \multirow{2}{*}{ Total } & \multirow{2}{*}{ Sig* } \\
\hline & Kurang & Cukup & Baik & Sangat Baik & & \\
\hline Tidak Lulus & 0 & 6 & 7 & 0 & 13 & 0.643 \\
\hline Lulus & 2 & 22 & 20 & 3 & 47 & \\
\hline Total & 2 & 28 & 27 & 3 & 60 & \\
\hline
\end{tabular}

$* p<0.05$

Tabel 3. Analisis butir pernyataan dengan hasil self assessment

\begin{tabular}{|c|c|c|c|c|c|c|c|c|c|c|}
\hline \multirow{3}{*}{ Butir Pernyataan } & \multicolumn{10}{|c|}{ Self Assessment } \\
\hline & \multicolumn{2}{|c|}{ Kurang } & \multicolumn{2}{|c|}{ Cukup } & \multicolumn{2}{|c|}{ Baik } & \multicolumn{2}{|c|}{$\begin{array}{c}\text { Sangat } \\
\text { Baik }\end{array}$} & \multicolumn{2}{|c|}{ Total } \\
\hline & $\mathrm{n}$ & $\%$ & $\mathrm{n}$ & $\%$ & $n$ & $\%$ & $\mathrm{n}$ & $\%$ & $\mathrm{n}$ & $\%$ \\
\hline $\begin{array}{l}\text { Pemahaman level kompetensi klinik } \\
\text { dari kasus yang dihadapi }\end{array}$ & 2 & 3.3 & 25 & 41.7 & 30 & 50.0 & 3 & 5.0 & 60 & 100.0 \\
\hline $\begin{array}{l}\text { Dasar keilmuan tentang teknik } \\
\text { pengambilan data dan manajemen } \\
\text { klinik }\end{array}$ & 3 & 5.0 & 28 & 46.7 & 25 & 41.7 & 4 & 6.7 & 60 & 100.0 \\
\hline $\begin{array}{l}\text { Dasar keilmuan tentang kasus yang } \\
\text { dihadapi }\end{array}$ & 6 & 10.0 & 23 & 38.3 & 26 & 43.3 & 5 & 8.3 & 60 & 100.0 \\
\hline $\begin{array}{l}\text { Anamnesis Sacred Seven yang } \\
\text { relevan }\end{array}$ & 5 & 8.3 & 11 & 18.3 & 31 & 51.7 & 13 & 21.7 & 60 & 100.0 \\
\hline $\begin{array}{l}\text { Anamnesis Fundamental Four yang } \\
\text { relevan }\end{array}$ & 4 & 6.7 & 7 & 11.7 & 40 & 66.7 & 9 & 15.0 & 60 & 100.0 \\
\hline Pemeriksaan fisik yang relevan & 4 & 6.7 & 23 & 38.3 & 28 & 46.7 & 5 & 8.3 & 60 & 100.0 \\
\hline Pemeriksaan fisik yang sistematik & 6 & 10.0 & 31 & 51.7 & 17 & 28.3 & 6 & 10.0 & 60 & 100.0 \\
\hline Teknik pemeriksaan fisik & 6 & 10.0 & 26 & 43.3 & 23 & 38.3 & 5 & 8.3 & 60 & 100.0 \\
\hline $\begin{array}{l}\text { Kemampuan interpretasi hasil } \\
\text { anamnesis dan pemeriksaan fisik }\end{array}$ & 5 & 8.3 & 25 & 41.7 & 23 & 38.3 & 7 & 11.7 & 60 & 100.0 \\
\hline
\end{tabular}


Andra N. et al.

\begin{tabular}{|c|c|c|c|c|c|c|c|c|c|c|}
\hline Diagno sis banding & 3 & 5.0 & 28 & 46.7 & 27 & 45.0 & 2 & 3.3 & 60 & 100.0 \\
\hline $\begin{array}{l}\text { Tindakan/teknik/saran pemeriksaan } \\
\text { penunjang yang relevan }\end{array}$ & 4 & 6.7 & 29 & 48.3 & 24 & 40.0 & 3 & 5.0 & 60 & 100.0 \\
\hline $\begin{array}{l}\text { Kemampuan interpretasi hasil } \\
\text { pemeriksaan penunjang dengan } \\
\text { benar }\end{array}$ & 13 & 21.7 & 25 & 41.7 & 18 & 30.0 & 4 & 6.7 & 60 & 100.0 \\
\hline Penentuan diagnosis kerja & 3 & 5.0 & 17 & 28.3 & 30 & 50.0 & 10 & 16.7 & 60 & 100.0 \\
\hline Tatalaksana non farmakoterapi & 3 & 5.0 & 28 & 46.7 & 26 & 43.3 & 3 & 5.0 & 60 & 100.0 \\
\hline Tatalaksana farmakoterapi & 15 & 25.0 & 24 & 40.0 & 16 & 26.7 & 5 & 8.3 & 60 & 100.0 \\
\hline $\begin{array}{l}\text { Komunikasi dengan bahasa yang } \\
\text { santun dan dapat dimengerti }\end{array}$ & 4 & 6.7 & 12 & 20.0 & 37 & 61.7 & 7 & 11.7 & 60 & 100.0 \\
\hline $\begin{array}{l}\text { Membina hubungan baik dengan } \\
\text { pasien dan atau keluarga secara } \\
\text { verbal dan non verbal }\end{array}$ & 0 & 0.0 & 13 & 21.7 & 39 & 65.0 & 8 & 13.3 & 60 & 100.0 \\
\hline $\begin{array}{l}\text { Memberi kesempatan pasien untuk } \\
\text { bercerita tentang penyakitnya }\end{array}$ & 0 & 0.0 & 14 & 23.3 & 35 & 58.3 & 11 & 18.3 & 60 & 100.0 \\
\hline $\begin{array}{l}\text { Melibatkan pasien dalam membuat } \\
\text { keputusan klinik }\end{array}$ & 7 & 11.7 & 18 & 30.0 & 27 & 45.0 & 8 & 13.3 & 60 & 100.0 \\
\hline $\begin{array}{l}\text { Memberikan edukasi sesuai kasus } \\
\text { pasien }\end{array}$ & 2 & 3.3 & 28 & 46.7 & 24 & 40.0 & 6 & 10.0 & 60 & 100.0 \\
\hline $\begin{array}{l}\text { Informed consent sebelum } \\
\text { melaku kan pemeriksaan fisik }\end{array}$ & 0 & 0.0 & 8 & 13.3 & 37 & 61.7 & 15 & 25.0 & 60 & 100.0 \\
\hline $\begin{array}{l}\text { Melakukan prosedur proteksi } \\
\text { terhadap hal yang membahayakan } \\
\text { diri sendiri dan orang lain }\end{array}$ & 2 & 3.3 & 21 & 35.0 & 33 & 55.0 & 4 & 6.7 & 60 & 100.0 \\
\hline $\begin{array}{l}\text { Memperhatikan kenyamanan } \\
\text { pasien }\end{array}$ & 1 & 1.7 & 21 & 35.0 & 29 & 48.3 & 9 & 15.0 & 60 & 100.0 \\
\hline $\begin{array}{l}\text { Melakukan tindakan sesuai } \\
\text { prioritas }\end{array}$ & 3 & 5.0 & 25 & 41.7 & 29 & 48.3 & 3 & 5.0 & 60 & 100.0 \\
\hline $\begin{array}{l}\text { Menunjukkan rasa hormat kepada } \\
\text { pasien }\end{array}$ & 1 & 1.7 & 13 & 21.7 & 33 & 55.0 & 13 & 21.7 & 60 & 100.0 \\
\hline $\begin{array}{l}\text { Mengetahui keterbatasan dengan } \\
\text { merujuk atau melakukan konsultasi } \\
\text { bila diperlukan }\end{array}$ & 2 & 3.3 & 22 & 36.7 & 28 & 46.7 & 8 & 13.3 & 60 & 100.0 \\
\hline Manajemen waktu & 19 & 31.7 & 20 & 33.3 & 16 & 26.7 & 5 & 8.3 & 60 & 100.0 \\
\hline Pencatatan rekam medik & 17 & 28.3 & 22 & 36.7 & 18 & 30.0 & 3 & 5.0 & 60 & 100.0 \\
\hline Performa saat di bawah tekanan & 19 & 31.7 & 29 & 48.3 & 10 & 16.7 & 2 & 3.3 & 60 & 100.0 \\
\hline Performa secara keseluruhan & 3 & 5.0 & 34 & 56.7 & 21 & 35.0 & 2 & 3.3 & 60 & 100.0 \\
\hline
\end{tabular}

Penilaian diri yang lebih rendah bila dibandingkan dengan kompetensi klinik yang sebenarnya akan lebih baik jika dibandingkan dengan penilaian diri yang berlebihan. Penilaian diri yang berlebihan oleh seseorang dengan kompetensi klinik yang rendah dapat menyebabkan seseorang kehilangan motivasi untuk melakukan perbaikan konsep belajar. ${ }^{16}$ Penilaian diri yang kurang tepat dapat berisiko membahayakan pasien. $^{17}$

Analisis statistik menggunakan uji Chi-Square diperoleh kesimpulan bahwa tidak ada hubungan yang signifikan $(\mathrm{p}>0,05)$ antara self assessment dengan kompetensi klinik mahasiswa. Hal ini menunjukkan bahwa self assessment terhadap kompetensi klinik belum dapat memberikan gambaran kompetensi klinik yang sebenarnya dimiliki oleh mahasiswa.

Hasil ini berbeda dengan apa yang ditemukan oleh Ward et al, yang menyebutkan bahwa terdapat korelasi antara self assessment mahasiswa dengan penampilan kliniknya. ${ }^{9}$ Koefisien korelasi penelitian tersebut berada pada tingkat korelasi rendah sampai sedang. Self assessment bukan merupakan sesuatu yang mudah untuk dilakukan. Tidak adanya hubungan yang signifikan antar variabel penelitian ini dapat disebabkan 
karena beberapa hal yaitu mahasiswa masih terbiasa memperoleh umpan balik dari luar dirinya, praktik penilaian diri untuk menilai kompetensi klinik baru sekali ini dilakukan oleh mahasiswa, atau instruksi intrumen yang kurang dipahami oleh responden.

Goodrich menyebutkan beberapa hal yang harus dilakukan supaya dapat melakukan penilaian diri yang efektif. ${ }^{2}$ Hal-hal tersebut antara lain : kesadaran akan pentingnya melakukan penilaian diri, memahami kriteria penilaian, adanya tugas yang akan dinilai, model penilaian diri, petunjuk atau instruksi dalam melakukan penilaian diri, latihan, mengetahui waktu yang tepat dalam melakukan penilaian diri, serta kesempatan atau peluang untuk melakukan perbaikan di tugas selanjutnya.

\section{KESIMPULAN}

Penilaian diri penting dalam membantu mahasiswa untuk secara mandiri menilai pencapaian kompetensi kliniknya saat ini, mengidentifikasi kekuatan dan kelemahan diri, untuk selanjutnya melakukan upaya-upaya perbaikan dan pengembangan diri untuk mencapai tujuan yang diharapkan. Hasil yang menunjukkan bahwa tidak ada hubungan yang signifikan antara self assessment dan kompetensi klinik mahasiswa pada penelitian ini, perlu diteliti lebih jauh lagi. Latihan dalam melakukan penilaian diri secara terus menerus diharapkan mampu memberikan gambaran kompetensi klinik yang sebenarnya dikuasai oleh mahasiswa tersebut. Intrumen yang digunakan dalam penelitian ini pun masih mungkin untuk dikembangkan sehingga betul-betul mampu menilai kompetensi klinik di diri masing-masing mahasiswa.

\section{DAFTAR PUSTAKA}

1. Standar Kompetensi Dokter Indonesia. Jakarta : Konsil Kedokteran Indonesia. 2012.

2. Andrade HL. Students as the definitive source of formative assessment: academic self-assessment and the self-regulation of learning. NERA Conference Proceeding. 2010, 25:3.

3. Sebba J, Crick R., Yu G, Lawson H, Harlen W, Durant K. Systematic review of research evidence of the impact on students of self- and peer-assessment.
Protocol. In: Research Evidence in Education Library. London: EPPI-Centre, Social Science Research Unit, Institute of Education, University of London. 2008.

4. Boud D, Falchikov N. Aligning assessment with long-term learning. Assessment \& Evaluation in Higher Education. 2006. 31(4):400.

5. Bostock S. Student peer assessment. The hgher education academy. 2000. (diunduh 18 Mei 2015). ht t p : / w w w.reading. a c.uk/web/FILE S / engageinassessment/Student_peer_assessmentStephen_Bostock.pdf.

6. McMillan JH, Hearn J.. Student self-assessment: the key to stronger student motivation and higher achievement. 2008. (diunduh 18 Mei 2015). http:// files.eric.ed.gov/fulltext/ EJ815370.pdf.

7. Standar Pendidikan Profesi Dokter Indonesia. Jakarta : Konsil Kedokteran Indonesia. 2012.

8. Wimmer PF. Developing clinical competence. Netherlands : Printpartners Impskamp B.V. 2006

9. Ward M, Gruppen L, Regehr G. Measuring selfassessment current state of the art. Adv Health Sci Educ Theory Pract. 2002. 7:63-80.

10. Ross JA. The reliability, validity, and utility of selfassessment. Practical Assessment, Research \& Evaluation. 2006. 11(10):1

11.Pisklakov S, Rimal J, McGuirt S. Role of self evaluation and self-assessment in medical student and resident education. British Journal of Education, Society \& Behavioral Science. 2014. 4(1):2.

12.Mardapi D. Teknik penyusunan isntrumen tes dan non tes. Yogyakarta : Mitra Cindikia; 2008.

13.Arikunto S. Dasar-dasar evaluasi pendidikan. Jakarta : Bumi Aksara; 2012

14.Morris H, Ryan C, Lauchlan D, Field M. Do medical student attitudes towards patients with chronic low back pain improve during training? A cross-sectional study. BMC Med Educ. 2012, 12:10.

15.Ochsmann EB, Zier U, Drexler D, Schmid K. Well prepared for work? Junior doctors' self-assessment after medical education. BMC Med Educ. 2011, 11:99. 
134 Andra N. et al.

16.Duffy FD, Holmboe ES. Self-assessment in lifelong learning and improving performance in practice: physician know thyself. JAMA. 2006. 296(9):11371139.

17.Davis D A, Mazmanian P E, Fordis M, Van Harrison R, Thorpe K E, Perrier L. Accuracy of physician self-assessment compared with observed measures of competence: a systematic review. JAMA. 2006. 296(9): 1094-1102. 